\title{
The Study of Superstition in Behavioral Sciences: Discussing Experimental Arrangements and Theoretical Assumptions
}

\author{
Natália Santos Marques ${ }^{1}$ \\ Universidade de São Paulo, São Paulo, SP, Brazil \\ Centro Universitário Católica de Quixadá, Quixadá, CE, Brazil \\ Marcelo Frota Lobato Benvenuti \\ Universidade de São Paulo, São Paulo, SP, Brazil \\ Instituto Nacional de Ciência e Tecnologia sobre Comportamento, Cognição e Ensino
}

\begin{abstract}
Superstition has been analyzed in behavioral sciences through the use of several terms (e.g., superstition, superstitious behavior, superstitious rules, and superstitious beliefs). This paper argues that the interpretation of the results of studies on superstition depend on: a) the experimental arrangements that are used to study this subject, $b$ ) what each of these arrangements enable us to conclude about behavioral relations, and c) assumptions about the role that is attributed to verbal behavior during the construction of superstitions. The role that is attributed to verbal behavior and the experimental arrangements that are chosen are related to underlying concepts of the effects of environmental variables on the control of behavior, namely whether these variables have a direct or indirect (mediational) effect over behavior. Based on these discussions, an alternative course of action is to emphasize existing functional relations between variables as a direct contingency effect, regardless of whether these variables or effects are verbal or nonverbal..
\end{abstract}

Keywords: experimental psychology, superstition, superstitious behavior, verbal behavior, contingency analysis.

\section{O Estudo da Superstição nas Ciências do Comportamento: Debatendo Procedimentos Experimentais e Concepções Teóricas}

\section{Resumo}

A superstição tem sido analisada nas ciências do comportamento por meio do uso de diversos termos (e.g., superstição, comportamento supersticioso, regras supersticiosas e crenças supersticiosas). Neste artigo, argumenta-se que a diversidade terminológica, bem como na interpretação dos resultados dos estudos sobre superstição se relaciona aos procedimentos experimentais usados para investigar esse

Mailing address: Av. L, 1771, conj. Bancários, Barra do Ceará, Fortaleza, CE, Brazil 60348-300. E-mail: nataliamarq@yahoo.com.br and marcelobenva@gmail.com

Support for this manuscript was provided by Fundação de Apoio à Pesquisa do Estado de São Paulo [FAPESP; grant no. 2011/22216-0, Ilusão de controle e a seleção do comportamento: o papel das variáveis sociais e culturais (Illusion of control and selection of behavior: the role of social and cultural variable)] to Marcelo Benvenuti and by National Council for Scientific and Technological Development (CNPq), doctoral scholarship grant to Natalia Santos Marques (grant no. 145774/2012-0).

Preparation of the manuscript were also supported by CNPq (grant \# 573972/2008-7) and FAPESP (grant \# 08/57705-8), both for the Instituto Nacional de Ciência e Tecnologia sobre Comportamento, Cognição e Ensino (INCT-ECCE), coordinated by Dra. Deisy G. de Souza (Universidade Federal de São Carlos [UFSCar]). 
tema, ao que cada um desses procedimentos permite concluir sobre relações comportamentais e às concepções sobre o papel atribuído ao comportamento verbal na constituição das superstições. Ainda, argumenta-se que o papel atribuído ao verbal e os procedimentos experimentais escolhidos se baseiam nos pressupostos sobre os efeitos das variáveis ambientais no controle do comportamento, ou seja, se essas variáveis tem um efeito direto ou indireto (mediado) sobre o comportamento. A partir dessas discussões, a ênfase nas relações funcionais existentes entre variáveis ambientais e comportamentais como efeitos diretos das contingências é discutida como um curso de ação alternativa capaz de lidar com os aspectos verbais e não verbais relacionados à superstição.

Palavras-chave: Psicologia experimental, superstição, comportamento supersticioso, comportamento verbal, análise de contingências.

\section{El Estudio de la Supertición en Ciencias de la Conducta: Debatiendo Procedimientos Experimentales y Concepciones Teoricas}

\section{Resumen}

La superstición ha sido analizada en las ciencias de la conducta por medio del uso de diversos términos (e.g., superstición, conducta supersticiosa, reglas supersticiosas y creencias supersticiosas). En este artículo, se argumenta que la diversidad terminológica, bien como en la interpretación de los resultados de los estudios sobre superstición se relaciona a los procedimientos experimentales usados para investigar esse tema, al que cada uno de estos procedimientos permite concluir sobre relaciones comportamentales y a las concepciones sobre el papel asignado a la conducta verbal en la constitución de las supersticiones. Aún, se argumenta que el papel asignado al verbal y los procedimentos experimentales elegidos se basan en los presupuestos sobre los efectos de las variables ambientales en el control de la conducta, $\mathrm{o}$ sea, se essas variables tienen un efecto directo o indirecto (mediado) sobre la conducta. A partir de essas discusiones, la énfasis em las relaciones funcionales existentes entre variables ambientales y comportamentales como un efecto directo de las contingencias es discutida como un curso de acción alternativa capaz de lidiar con los aspectos verbales y no verbales relacionados a la superstición.

Palabras clave: Psicología experimental, superstición, conducta supersticiosa, conducta verbal, análisis de contingencias.

Since its first proposals for experimental investigation, the use of the term "superstition" has been related to different arrangements of contingencies and their effects. In the classic study "Superstition in the pigeon" Skinner (1948/1961) observed a curious phenomenon after programming the presentation of food according to fixed-time schedule of $15 \mathrm{~s}$. Although food presentation occurred independently of any behavior, the responses that preceded food reinforcement were strengthened in some of the pigeons. According to Skinner, "the experiment might be said to demonstrate a sort of [italics added] superstition" (Skinner, 1948/1961, p. 407). This can be referred to as a molecular effect of accidental reinforcement (Skinner, 1953, 1948/1961) or molar effect of an accidental correlation between responses and reinforcement (Herrnstein, 1966). Later, Skinner (1953) added, "Only a small part of the behavior strengthened by accidental contingencies develops into the ritualistic practices which we call 'superstitions,' but the same principle is at work" (p. 86). Human superstitious rituals diverge from the simple effect of a responseindependent reinforcer because they usually deal with the participation of verbal behavior, and they are transmitted as part of the culture. Skinner latter pointed out the possibility of establishment of a "second kind of superstition", 
an accidental stimulus control (an effect that was directly investigated by Morse \& Skinner, 1957). In Morse and Skinner study, pigeons pecked on a variable-interval schedule of reinforcement. Once per hour, a blue light was projected on the key for 4 min. For some subjects, the light was presented and occasionally followed by food as a reinforcer. For the other subjects, the light was occasionally followed by periods of no food delivery. After some presentations, the light was accidentally correlated with the presence or absence of reinforcers, causing variations in responses across subjects, even though it was not correlated to any change in the probability of reinforcement.

Thus, the same term, "superstition" was used to designate accidental reinforcing and discriminative effects in individual behavior, in addition to ritualistic cultural practices. Such multiplicity of meanings that were related to the general idea of superstition is still remarkable in studies on this issue. Many terms have also been added to the discussion, including "superstitious conditioning" (Gleeson, Lattal, \& Williams, 1989), "concurrent or topographic superstition" (Catania \& Cutts, 1963), "social transmission of superstitious behavior" (Higgins, Morris, \& Johnson, 1989), "sensory superstition" (Starr \& Staddon, 1982), "superstitious rules" (Ninness \& Ninness, 1999; Rudski, Lischner, \& Albert, 1999), "superstitious self-generated rules" (Ninness \& Ninness, 1998), "superstitious beliefs" (Heltzer \& Vyse, 1994; Rudski, 2004), "superstitious perception" (Mellon, 2009), and "magical, paranormal, and superstitious beliefs" (Lindeman \& Aarnio, 2006).

As pointed out by Rudski (2003), the lack of clarity on how to use the terms to study superstition can cause a series of problems, such as difficulties in delimiting the phenomenon being studied, defining how superstitions are established and maintained, identifying the connection between superstition and other psychological constructs, and relating research data that have distinct concepts of superstition. To achieve more precise terminology, some researchers divided superstitions into categories (e.g., Grimmer \& White, 1992; Jahoda, 1969). However, as Rudski highlighted, despite these attempts there is still much confusion in determining what is meant by superstition. According to Vyse (1997), a common aspect of a great variety of studies on superstition is investigation of the effects of coincidence (in both time and space) between behavioral and environmental events. In agreement with Vyse, we define superstition as the different behaviors that are controlled by environmental events that are independent of the subject's behavior.

Through the analysis of selected studies that deal directly or indirectly with superstition, this paper discusses that the different meanings regarding superstition are related mostly to the experimental arrangements and diferent underlying conceptions about causal learning and behavior. We will discuss the need to better understand the role that verbal behavior plays in superstitious as way to integrate different theoretical questions. Similar analysis was made by Delgado (2015) in the context of experimental study of causal learning to discuss the effects that are generated in limited and unlimited-timeto-respond tasks as a result of the interference of rule generation. This analysis gave centrality to experimental features and verbal behavior in one study of causal learning.

In a perspective more influenced by behavioristic account of superstitious behavior (Skinner, 1948/1961), verbal behavior (Skinner, 1957) and the notion of contingencies of reinforcement in a more general way, this paper try to organize the different behavioral functions that can be assumed by verbal variables ${ }^{2}$ in superstitions. Exploring contributions from this perspective on learning and behavior can contribute to rich debates in psychology, as about positive and negative aspects of causal learning and its bias (Blanco, 2017).

2 We sometimes use the term "verbal variables" instead of "verbal behavior" to refer both to participants' verbal behavior and to verbal variables which control participants' behavior (e.g., the verbal behavior of the experimenter or confederate, or another participant). 


\section{Main Experimental Arrangements and the Role of Verbal Behavior in the Characterization of Superstition}

In Skinner (1948/1961) arrangement to study superstitious behavior, a particular event (e.g., points, food, water, or a message of "good" or potentially aversive events, such as messages of "bad" or unpleasant tones) appears at pre-defined intervals after the last presentation. This is an example of a stimulus-stimulus contingency because the dependency relation that is programmed by the experimenter is between events and not between responses and environmental events. Programming time-intervals for presenting or removing events for the study of superstitious behavior is a strategy that was used with pigeons (Eldridge, Pear, Torgrud, \& Evers, 1988; Gleeson et al., 1989; Neuringer, 1970; Reberg, Innis, Mann, \& Eizenga, 1978; Skinner, 1948/1961; Timberlake \& Lucas, 1985), rats (Domjan \& Rowell, 1969; Reberg, Mann, \& Innis, 1977), and humans (Aeschleman, Rosen, \& Williams, 2003; Bloom, Vernad, Harden, \& Seetharaman, 2007; Higgins et al., 1989; Ono, 1987; Wagner \& Morris, 1987; Weisberg \& Kennedy, 1969). This strategy permits the observation of behavioral changes along the exposure to the planned contingency between stimuli presentation. A common effect is superstitious behavior that can be explained by accidental correlation to reinforcement.

The adequacy of a reinforcement-based account of superstition has been questioned by other studies that also investigated behavior generated by schedules of noncontingent events (e.g., Rescorla \& Skucy, 1969; Staddon \& Simmelhag, 1971; Timberlake \& Lucas, 1985). As discussed by these studies, long exposition to stimuli-stimuli contingency can be responsible for the emergence of behavior patterns that can be better accounted as species-typical responses. Thus, others procedures that clearly shows the effect of reinforcement can be more advantageous to study superstitious behavior. One of the strategies involves the analysis of responding after a transition from a response-dependent to response-independent schedule of reinforcement (e.g., Appel \& Hiss, 1962; Neuringer, 1970). Other strategy that can be mentioned to study the effect of reinforcement in superstition is the analysis of maintenance of responding by a reinforcement that is produced by a different response (e.g., Catania \& Cutts, 1963; Pear, 1985). Finally, to study accidental stimulus control, it is possible to evaluate differential response rates in noncontingent stimulus changes superimposed on contingent schedules of reinforcement (e.g., Morse \& Skinner, 1957; Ono, 1987; Starr \& Staddon, 1982). These procedures permit the assessment of behavioral effects that are produced by the presentation of noncontingent events in the interaction with the reinforcing contingency.

It is also important to mention another group of procedures that deal with the notion of ilusion of control ${ }^{3}$ and can be related to investigative efforts to understand superstition. The basic strategy demand defining, previously to the experimental task, the percentage of trials in which a certain event (e.g., turn a light on or off at the end of one trial) is presented after occurrence of behavior. A "percentage of control" over presentation of the event can be calculated by subtracting the percentage of event presence in the absence of a response from the percentage of the same event after the occurance of response (e.g., Alloy \& Abramson, 1979). By the end of the sessions, with similar contingencies experimenters usually ask the subjects to judge the degree of control they had over the presentation of the event (e.g., Alloy \& Abramson, 1979; Blanco, Matute, \& Vadillo, 2009, 2011, 2012; Matute, 1993, 1994, 1995, 1996; Matute, Vadillo, Vegas, \& Blanco, 2007; Matute, Yarritu \& Vadillo, 2011; Vadillo, Matute, \& Blanco, 2013). Behavior produced in this kind of situation sometimes is called "superstitious" (e.g. Matute, 1993, 1994, 1995;

\footnotetext{
The notion of illusion of control refers to situations in which the subjects have little or no control over the environmental changes but report a high level of control, overestimating the relationship between their actions and outcomes. In Langer's (1975) definition, the illusion of control is an expectation of control regarding the environment that is higher than the actual condition.
} 
Matute et al., 2011) and when people judge that they are controlling uncontrollable events, illusion of control sometimes is discussed as the basis for superstitions (e.g. Blanco et al., 2011; Matute et al., 2007).

The analysis of these experimental situations shows that although using the same terms (such as "superstition" and derivatives thereof), the investigations may sometimes deal with distinct phenomena and theoretical assumptions concerning how learning is related to superstition. The analysis of the estimate of control/ self-reports as a measure of the effects of response-independent environmental events is historically related to the perspective that environmental events produce behavioral effects through processes of interpretation or verbal discrimination of reality. It was based on this assumption that assessing the participant's statements (often on numerical scales, ranging from "full control" to "no control") became a very widespread practice in research on the illusion of control. This strategy was inspired by an initial study by Jenkins and Ward (1965) and considered by Alloy and Abramson (1979) as an alternative to assessing the "subjective representation of contingencies" in learning, as opposed to what the "real contingency" would be.

Estimates of control are themselves (verbal) behavior. As such, they can be explained by the actual contingencies of reinforcement that act in the moment (Skinner, 1957, 1969). Behaving in response to a given environmental event and discriminating one's own behavior are functionally independent behavioral repertoires (Killeen, 1978; Lattal, 1975, 1979). A study that offers contributions to this discussion was conducted by Killeen (1978), who aimed to oppose two causal assumptions that are related to superstition. According to one of these assumptions, the "bias" of behavior consists of direct strengthening effects. The second assumption predicts the occurrence of detection processes as behavioral mediators in the creation of a "bias" on behavior. The experiment investigated whether pigeons are able to provide accurate judgments of causality and sought to determine which variables affect such judgments. Every time the pigeons pecked a central key, there was a .05 probability of illuminating two side keys. While the pigeons pecked the central key, a computer created pseudo-pecks at the same rate, with each pseudo-peck also having a probability of .05 of illuminating the side keys. The pigeon's task was "describing" whether the change in stimulus (illuminating the side keys) had been produced because of their last peck or whether it happened independently of that peck. The pigeons' "description" consisted of pecking the side keys: the right one for "response-dependent" and the left one for "response-independent." Each correct description was reinforced by access to food for a period of time, which varied between 1.8 and $3.8 \mathrm{~s}$. Incorrect descriptions produced a brief time-out. The results showed that the pigeons had a high sensitivity to the contingency that was in force, so that they made the right choice in $80 \%$ of the trials in all of the reinforcement conditions. A shorter time interval between the last response and the noncontingent environmental change (high contiguity) was associated with a higher probability of "describing" that the change had been contingent on the pigeon's own behavior when, in fact, it was not. These data show that discriminating the relation of causality was likely based on the delay between one response and its effects. Thus, by maintaining constant the accuracy in identifying the contingencies that were in place, Killeen (1978) manipulated the relative payoff for for "response-dependent" and "response-independent" descriptions. Then, the animals biased their responses as a function of the relative payoff, maximizing their reinforcement and so showing that changes in their reports could vary regardless of the discriminability of the situation. By this way, the author has demonstrated that superstition is a matter of bias that is created by reinforcement and not a matter of detecting reality. These results and conclusions are compatible with the perspective that considers the effects of environmental variables to be direct (not mediated).

Despite the fact that they are functionally independent of non-verbal behavior, self-reports are sometimes used as evidence of non-verbal behavior. For example, Aeschleman et al. (2003) 
investigated the effects of response-independent events on verbal and non-verbal behavior in subjects who were exposed to poor and rich schedules of positive and negative reinforcement. The experimental demand consisted in to try to produce and/or maintain the word "GOOD" (positive reinforcement) or to try to prevent and/or remove the word "BAD" (negative reinforcement) from the computer screen using response keys. The independent variable in the study was the number of occurrences of the response followed by reinforcement and the number of occurrences of the response without reinforcement. The dependent variables were the response rate and the subject's estimate of control over the experimental situation. The results showed that subjects who were exposed to negative reinforcement conditions reported, on average, a higher estimate of control than participants who were exposed to positive reinforcement. Regarding non-verbal behavior, variations were observed in the mean response rates between the extinction and reinforcement conditions. According to Aeschleman et al., the differences that were observed between the effects on verbal and nonverbal behavior occurred because dependent variables provided different access to superstitious behavior, and the verbal report of the participants was a more accurate measure. Based on these assumptions, the authors pointed out that among subjects who were exposed to the arranged negative reinforcement was a higher occurrence of superstition, measured as judgment of high control over response-independent stimuli. Despite that, the variations that were observed in non-verbal behavior were tightly matched to the demands of the arranged contingency (see also Bloom et al., 2007). Matute (1994) also measure superstition based on verbal behavior. According to her, superstition must be based on the repeated occurrence of the nonverbal response that is required by the task and confirmed by the subject's report. To deal with experimental data that are produced in a noncontingent task, Matute (1994) stated that

a subject was classified as superstitious if she or he repeated the same response or pattern of responses during the last $n$ trials of the task and confirmed this superstition when asked about the correct cue to stop the tone. (p. 221)

The current analysis does not suggest that the use of verbal reports in research on superstition is incorrect, but it points out that special treatment of verbal behavior and proper control variables are needed. Correspondence between verbal and non-verbal behavior is possible, but both demand a contingency analysis and can be a function of different behavioral variables. More recent literature on superstitious behavior has provided interesting insights into the way in which non-verbal and verbal behavior can be related in different ways in experiments that evaluate superstitious behavior (e.g., Heltzer \& Vyse, 1994; Higgins et al., 1989; Leigland, 1996).

Heltzer and Vyse (1994), for example, investigated the effects of noncontingent reinforcement in participants' descriptions of contingencies. The participants were instructed to discover how to earn points. Points were earned for eight combined presses on two computer keys (four presses on each key). For the fixedratio 1 (FR1) group, each four-press sequence on each key was reinforced. For the FR2 group, two eight-press sequences were required. For the random-ratio 2 (RR2) group, a point was randomly given for $50 \%$ of the sequences. At the end, the participants were asked about what they should do to earn points. The descriptions that mentioned patterns of behavior that were not strictly demanded by the current contingencies were considered "superstitious". Based on this criterion, the authors observed more superstitious rules in the RR group than in the FR group. In Heltzer and Vyse study, the verbal response was the response under analysis and not an indirect measure of superstition.

Verbal behavior can also be maintained by an accidental correlation with reinforcement. Leigland (1996) reinforced verbal behavior of participants by differential reinforcement of successive approximations to a topic. Afterward, the reinforcers were presented noncontingently at the same frequency and distribution as the first phase of the experiment. Finally, the reinforcers became contingent on a topic that was 
different from Phase 1. Generally, the contingent reinforcement strengthened the ongoing verbal behavior of the subjects, and interruption of the contingency in Phase 2 decreased the previously selected verbal behavior or replaced the topic. For one subject, the replacement of the topic during the noncontingent reinforcement phase indicated the adventitious selection of verbal behavior. According to Leigland, certain terms that occurred in temporal proximity to a presented reinforcement reoccurred several times shortly thereafter and not at other times.

The analysis of the role of verbal variables in superstitions includes its manipulation as an independent variable. Higgins et al. (1989) suggested an experimental procedure to investigate the social transmission of superstition. In this study, three different experimental settings were programmed, with differences in the relation of the programmed combination between social stimuli and non-social noncontingent reinforcement. The noncontingent reinforcement contingency corresponded to a multiple variable-time (VT) 15-s and extinction (EXT) schedule. The social stimuli that were manipulated corresponded to the instructions about the experimental tasks and modeling. The results indicated that the responses were more frequent during the VT intervals than during the EXT intervals, thus indicating interactions between the social variables and the noncontingent presentation of reinforcements. This kind of experimental setting enables assessments of the transmission of superstitious behavior across individuals and makes it possible to investigate the role of verbal behavior (and other social variables) as antecedent variables that participate in the control of superstitions. These different roles that have been attributed to the verbal variable, depending on assumptions about the effects of environmental variables in controlling behavior and the kind of superstitious behavior that is investigated, shows that it is mandatory to have more accuracy in identifying the role of the verbal variable in superstition. As an alternative to investigating this subject, we emphasize Skinner's account of verbal behavior, in which verbal behavior (as all behaviors) is a direct effect of contingency (without mediation mechanism of perception of reality that guided behavior). This perspective contributes to clarifying the different roles that the verbal variable may play in superstitious behavioral phenomena (e.g., as a superstitious response or as an environmental stimulus that controls superstitious responses).

\section{More Specification of the Role of Verbal Behavior Is Needed in the Critical Evaluation of "Superstition" and "Superstitious Behavior"}

A favorable assertion about the use of such terms as "superstition" and "superstitious behavior" in behavioral sciences is that such a practice enables communication between researchers. Another assertion is that these terms allow direct parallels between basic research and behaviors that frequently occur outside the experimental context. However, studies on superstition show remarkable differences in the variables that are being measured and analyzed. These studies also differ with regard to the assumptions that are the basis of their analyses, thus creating differences in the procedures that are used, the results that are generated, and the interpretations of these results. For this reason, it is understood that such terms have not favored dialog among researchers or comparisons between data.

Ono (1994) offered an important contribution to systematizing different behavioral relations based on which contingency links involve independent relations. Figure 2 was adapted from Ono (1994), showing various types of superstitious behavior and distinguishing them according to where independent relations exist among three terms of reinforcement contingency. Ono's reference to autoshaping was excluded from this figure because its relation with other types of behaviors under response-independent contingencies was not further explored in the literature.

Thus, contiguous relations may occur: (a) between the presentation of the reinforcement and the occurrence of a response (e.g., simple superstitions identified by Skinner, 1948/1961); (b) between the occurrence of reinforcement and certain environmental stimuli that gain adven- 
Response independent contingencies

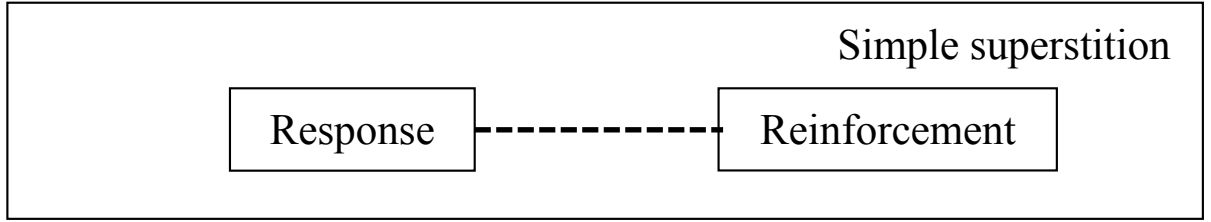

Response dependent contingencies

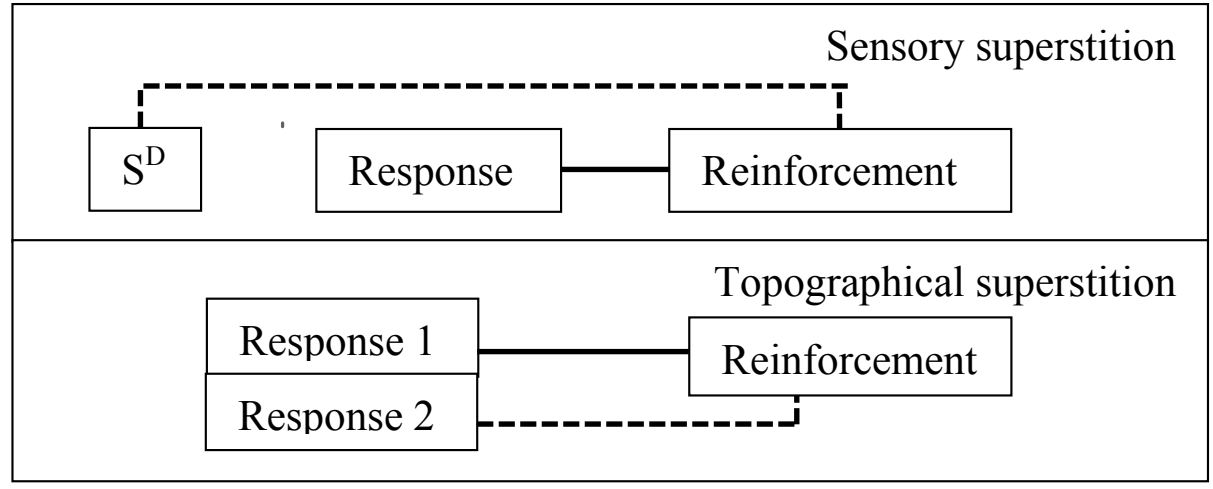

Figure 1. Types of superstitious behavior, distinguished according to where independent relations exist among three terms of reinforcement contingencies (Adapted from Ono, 1994). Continuous lines indicate contingency relationships, while dashes ones indicate only contiguity.

titious discriminatory control over responding (e.g., sensory superstitions identified by Morse \& Skinner, 1957); and (c) between a certain response and the reinforcement that is produced by another response, which follows the first (e.g., topographical superstitions identified by Catania $\&$ Cutts, 1963). Different manipulations of these dependency relations (e.g., the types of stimuli used, manipulated time proximity, and the number of contiguous occurrences) can contribute to delimiting these phenomena based on the relation of control between variables (e.g., Lattal, 1973, 1974; Sizemore \& Lattal, 1977). Investigations such as these enable a better understanding of ongoing relations of control for different behaviors that are controlled by noncontingent environmental events.

To better comprehend these relations, in addition to highlighting which contingency links involve independent relations, the study of behavioral effects produced by responseindependent events must emphasize the role that is played by verbal variables (if any) in the planned contingency setting. As shown in Figure 1 , the verbal variable in an experimental setting may correspond to a manipulated environmen- tal event (i.e., an independent variable [IV]) or a response that is produced by the experimental condition (i.e., a dependent variable [DV]).

When it corresponds to a DV, the verbal variable consists of a response that is generated by the experimental condition. This response may consist of the target behavior that is strengthened by noncontingent reinforcement (e.g., Leigland, 1996), verbal behavior that is controlled by an antecedent stimulus that is unrelated to reinforcement, ulterior descriptions of their own performance in a noncontingent reinforcement task (e.g., estimate of control; Matute, 1994), or a response that is maintained by reinforcement that is produced by a different response, such as rules that are part of the control of the target non-verbal behavior (e.g., Heltzer \& Vyse, 1994). In the first case, the response may be characterized as simple superstition. In the second case, it may be characterized as a tact (Skinner, 1957); thus, the critical variables that must be investigated are antecedent events that control the verbal report. When the participant's responses are characterized as rules, as in the third case, it is essential to identify which ulterior behavior is being controlled by the self-rule. These rules can consist 


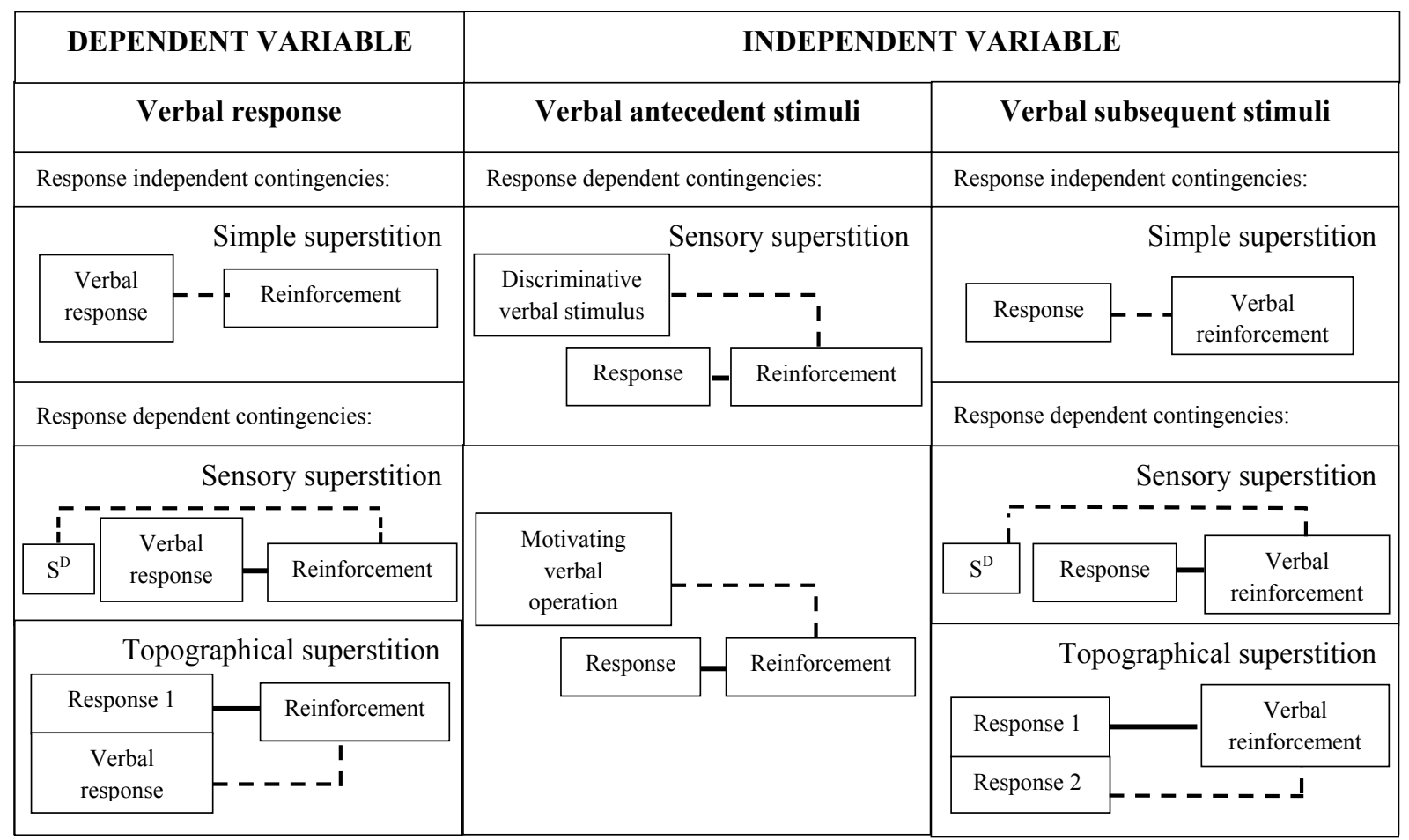

Figure 2. The function of a verbal variable in terms of independent variable (IV) and dependent variable (DV). Continuous lines indicate contingency relationships, while dashes ones indicate only contiguity.

of accurate descriptions of the environmental contingencies or behaviors that are adapted to these contingencies, or it can consist of verbal statements of contingencies that are not in effect. If supported by the environment, then these inaccurate descriptions may persist and control the forms of responding that are poorly matched to the requirements of the task (e.g., superstitious rules generated in Heltzer \& Vyse, 1994).

When it corresponds to an IV, the verbal variable may consist of an antecedent stimulus, like rules that function as a discriminative stimulus or motivating operation (e.g., instructions presented by Higgins et al., 1989) or in an event subsequent to the non-verbal response that is de- manded by the task (e.g., the words "good" and "bad" in Aeschleman et al., 2003). Such events may or may not be contingent on the responses that are required by the experimental task, depending on whether there are independent relations among the three terms of the reinforcement contingency.

The characterization of the verbal variable in terms of the IV and DV in studies on superstition facilitates the organization of the literature that deal with superstition. Also, this systematization connects verbal and non-verbal superstitions behavior. Table 1 summarizes some examples of different functions that have been assigned to verbal variable in the experimental studies of superstition.

Table 1

Different Functions Assigned to the Verbal Variable in Studies about Superstition

\begin{tabular}{ccc}
\hline Antecedent event & Response & Subsequent event \\
\hline Higgins et al. (1989) & Aeschleman et al. (2003) & Aeschleman et al. (2003) \\
Ninnes \& Ninnes (1998) & Bloom et al. (2007) & \\
Ono (1994) & Heltzer \& Vyse (1994) & \\
& Matute (1994) & \\
& Ono (1994) & \\
\hline
\end{tabular}


The analysis about the role of verbal variable in superstition helps to find similarities in the investigations. Hence, this proposal of systematization makes it easier to connect research data. It also contributes to solving another problem that was mentioned by Rudski (2003): delimiting the investigated phenomenon and consequently its relation with other behavioral phenomena. Lastly, the current proposal allows one to reconcile some phenomena that have been treated as essentially different based on a behavioral account of superstition, such as the illusion of control, contingency learning, and subjective representations of contingencies (e.g., Blanco, 2016; Delgado, 2015; Jenkins \& Ward, 1965; Langer, 1975). As pointed out by Benvenuti $(2010,2013)$, the notion of superstition is culturally linked to a series of phenomena which usually have interpretations based on concepts such as beliefs, illusions, and contact with reality as a mediation mechanism. The present analysis allows us to conclude that the behavioral effects generated by noncontingent events can be linked by verbal variables in different ways. Each of these ways opens a lot of opportunities to behavioral research that have the potential to increase our knowledge about superstition and also other behaviors of our daily lifes.

\section{References}

Aeschleman, S. R., Rosen, C. C., \& Williams, M. R. (2003). The effect of non-contingent negative and positive reinforcement operations on the acquisition of superstitious behaviors. Behavioural Processes, 61, 37-45. doi:10.1016/ S0376-6357(02)00158-4

Alloy, L. B., \& Abramson, L. Y. (1979). Judgment of contingency in depressed and nondepressed students: Sadder but wiser? Journal of Experimental Psychology: General, 108, 441-485. doi:10.1037/0096-3445.108.4.441

Appel, J. B., \& Hiss, R. H. (1962). The discrimination of contingent from noncontingent reinforcement. Journal of Comparative and Physiological Psychology, 55(1), 37-39. doi:10.1037/ h0044613
Benvenuti, M. F. L. (2010). Contato com a realidade, crenças, ilusões e superstições: Possibilidades do analista do comportamento. Perspectivas em Análise do Comportamento, 1, 34-43.

Benvenuti, M. (2013). Ilusão de controle e a seleção do comportamento. Boletim Contexto, 38, 3161.

Blanco, F. (2017). Positive and negative implications of the causal illusion. Consciousness and Cognition, 50, 56-68. doi:10.1016/j.con$\operatorname{cog} .2016 .08 .012$

Blanco, F., Matute, H., \& Vadillo, M. A. (2009). Depressive realism: Wiser or quieter? Psychological Record, 59, 551-562. Retrieved from http://opensiuc.lib.siu.edu/cgi/viewcontent. cgi?article $=1037 \&$ context $=$ tpr

Blanco, F., Matute, H., \& Vadillo, M. A. (2011). Making uncontrollable seem controllable: The role of action in the illusion of control. Quarterly Journal of Experimental Psychology, 64, 1290-1304. doi:10.1080/17470218.2011.55272 7

Blanco, F., Matute H., \& Vadillo M. A. (2012). Mediating role of activity level in the depressive realism effect. PLoS One, 7(9), e46203. doi:10.1371/journal.pone.0046203

Bloom, C. M., Vernad, J., Harden, M., \& Seetharaman, S. (2007). Non-contingent positive and negative reinforcement schedules of supersitious behaviors. Behavioural Processes, 75, 8-13. doi:10.1016/j.beproc.2007.02.010

Catania, A. C., \& Cutts, D. (1963). Experimental control of superstitious responding in humans. Journal of the Experimental Analysis of Behavior, 6, 203-208. doi:10.1901/jeab.1963.6-203

Delgado, D. (2015). Blocking in humans: Logical reasoning versus contingency learning. Psychological Record, 66, 31-40. doi:10.1007/s40732015-0148-x

Domjan, M. P., \& Rowell, J. W. (1969). Discrimination between escapable and inescapable shock. Psychological Reports, 24, 111-114. doi:10.2466/pr0.1969.24.1.111

Eldridge, G. D., Pear, J. J., Torgrud, L. J., \& Evers, B. H. (1988). Effects of prior response-contingent reinforcement on superstitious behavior. Animal Learning and Behavior, 16, 277-284. doi:10.3758/BF03209077 
Gleeson, S., Lattal, K. A., \& Williams, K. S. (1989). Superstitious conditioning: A replication and extension of Neuringer (1970). Psychological Record, 39, 563-571. Retrieved from http://search. proquest.com/openview/46854ac0cca0533e81e 80f9b4ed106c3/1?pq-origsite $=$ gscholar

Grimmer, M. R., \& White, K. D. (1992). Nonconventional beliefs among Australian science and nonscience students. Journal of Psychology, 126, 521-528. doi:10.1080/00223980.1992.105 43385

Heltzer, R. A., \& Vyse, S A. (1994). Intermittent consequences and problem solving: The experimental control of "superstitious" beliefs. Psychological Record, 44, 155-169. Retrieve from http:// digitalcommons.conncoll.edu/cgi/viewcontent. cgi ?article $=1004 \&$ context $=$ psychfacpub

Herrnstein, R. J. (1966). Superstition: A corollary of the principles of operant conditioning. In W. K. Honig (Ed.), Operant behavior: Areas of research and application (pp. 33-51). New York: Appleton-Century-Crofts.

Higgins, S. T., Morris, E. K., \& Johnson, L. M. (1989). Social transmission of superstitious behavior in preschool children. Psychological Record, 39, 307-323. Retrieved from http://search. proquest.com/openview/3edeae3e662fdd81524 1498a60a5d8f1/1?pq-origsite $=$ gscholar

Jahoda, G. (1969). The psychology of superstition. London: Allen Lane.

Jenkins, H. M., \& Ward, W. C. (1965). Judgment of contingency between responses and outcomes. Psychological Monographs: General and Applied, 79, 1-17. doi:10.1037/h0093874

Killeen, P. R. (1978). Superstition: A matter of bias, not detectability. Science, 199(4324), 88-90. doi:10.1126/science. 199.4324 .88

Langer, E. J. (1975). The illusion of control. Journal of Personality and Social Psychology, 32, 311328. doi:10.1037/0022-3514.32.2.311

Lattal, K. A. (1973). Response-reinforcer dependence and independence in multiple and mixed schedules. Journal of the Experimental Analysis of Behavior, 20, 265-271. doi:10.1901/ jeab.1973.20-265

Lattal, K. A. (1974). Combinations of response-reinforcer dependence and independence. Journal of the Experimental Analysis of Behavior, 22, 357362. doi:10.1901/jeab.1974.22-357
Lattal, K. A. (1975). Reinforcement contingencies as discriminative stimuli. Journal of the Experimental Analysis of Behavior, 23, 241-246. doi:10.1901/jeab.1975.23-241

Lattal, K. A. (1979). Reinforcement contingencies as discriminative stimuli: II. Effects of changes in stimulus probability. Journal of the Experimental Analysis of Behavior, 31, 15-22. doi:10.1901/ jeab.1979.31-15

Leigland, S. (1996). An experimental analysis of ongoing verbal behavior: Reinforcement, verbal operants, and superstitious behavior. Analysis of Verbal Behavior, 13, 79-104. Retrieved from http:/www.ncbi.nlm.nih.gov/pmc/articles/ PMC2748494/

Lindeman, M., \& Aarnio, K. (2006). Paranormal beliefs: Their dimensionality and correlates. European Journal of Personality, 20, 585-602. doi:10.1002/per.608

Matute, H. (1993). Efectos de la incontrolabilidad en humanos: ¿indefension o superstición? Revista de Psicología General y Aplicada, 46, 421-427.

Matute, H. (1994). Learned helplessness and superstitious behavior as opposite effects of uncontrollable reinforcement in humans. Learning and Motivation, 25, 216-232. doi:10.1006/ lmot.1994.1012

Matute, H. (1995). Human reactions to uncontrollable outcomes: Further evidence for superstitious rather that helplessness. The Quarterly Journal of Experimental Psychology, 48B, 142-157.

Matute, H. (1996). Illusion of control. Detecting response outcome independence in analytic but not in naturalistic conditions. Psychological Science, 7, 289-293. doi:10.1111/j.1467-9280.1996. tb00376.x.

Matute, H., Vadillo, M. A., Vegas, S, \& Blanco, F. (2007). Illusion of control in internet users and college students. Cyberpsychology \& Behavior, 10, 176-181. doi:10.1089/cpb.2006.9971.

Matute, H., Yarritu, I., \& Vadillo, M. A. (2011). Illusions of causality at the heart of pseudoscience. British Journal of Psychology, 102, 392-405. doi:10.1348/000712610X532210

Mellon, R. C. (2009). Superstitious perception: Response-independent reinforcement and punishment as determinants of recurring eccentric interpretations. Behaviour Research and Therapy, 47, 868-875. doi:10.1016/j.brat.2009.06.016 
Morse, W. H., \& Skinner, B. F. (1957). A second type of superstition in the pigeon. American Journal of Psychology, 70, 308-311. doi:10.2307/1419345

Neuringer, A. J. (1970). Superstitious key pecking after three peck-produced reinforcements. Journal of the Experimental Analysis of Behavior, 13, 127-134. doi:10.1901/jeab.1970.13-127

Ninness, H. A., \& Ninness, S. K. (1998). Superstitious math performance: Interactions between rules and scheduled contingencies. Psychological Record, 48, 45-62. Retrieved from http://opensiuc.lib.siu.edu/cgi/viewcontent. cgi? article $=1540 \&$ context $=$ tpr

Ninness, H. A., \& Ninness, S. K. (1999). Contingencies of superstition: self-generated rules and responding during second-order response-independent schedules. Psychological Record, 49, 221-243. Retrieved from http://opensiuc.lib.siu.edu/cgi/ viewcontent.cgi $?$ article $=1460 \&$ context $=$ tpr

Ono, K. (1987). Superstitious behavior in humans. Journal of the Experimental Analysis of Behavior, 47, 261-271. doi:10.1901/jeab.1987.47-261

Ono, K. (1994). Verbal control of superstitious behavior: Superstitions as false rules. In S. C Hayes, L. J. Hayes, M. Sato, \& K. Ono (Eds.), Behavior analysis of language and cognition (pp. 181-196). Reno, NV: Context Press.

Pear, J. J. (1985). Spatiotemporal patterns of behavior produced by variable-interval schedules of reinforcement. Journal of the Experimental Analysis of Behavior, 44, 217-231. doi:10.1901/ jeab.1985.44-217

Reberg, D., Innis, N. K., Mann, B., \& Eizenga, C. (1978). "Superstitious" behaviour resulting from periodic response-independent presentations of food or water. Animal Behaviour, 26, 507-519. doi:10.1016/0003-3472(78)90067-2

Reberg, D., Mann, B., \& Innis, N. K. (1977). Superstitious behavior for food and water in the rat. Physiology and Behavior, 19, 803-806. doi:10.1016/0031-9384(77)90318-3

Rescorla, R. A., \& Skucy, J. C. (1969). Effect of response-independent reinforcers during extinction. Journal of Comparative and Physiological Psychology, 67(3), 381-389. doi:10.1037/ h0026793

Rudski, J. M. (2003). What does a "superstitious" person believe? Impressions of participants. The
Journal of General Psychology, 130, 431-445. doi:10.1080/00221300309601168

Rudski, J. M. (2004). The illusion of control, superstitious belief, and optimism. Current Psychology, 22, 306-315. doi:10.1007/s12144-004-1036-8

Rudski, J. M., Lischner, M. I., \& Albert, L. M. (1999). Superstitious rule generation is affected by probability and type of outcome. Psychological Record, 49, 245-260. Retrieved from http://opensiuc.lib.siu.edu/cgi/viewcontent. cgi? article $=1461 \&$ context $=$ tpr

Sizemore, O. J., \& Lattal, K. A. (1977). Dependency, temporal contiguity, and response-independent reinforcement. Journal of the Experimental Analysis of Behavior, 27, 119-125. doi:10.1901/ jeab.1977.27-119

Skinner, B. F. (1953). Science and human behavior. New York: Macmillan

Skinner, B. F. (1957) Verbal Behavior. Cambridge, MA: B. F. Skinner Foundation.

Skinner, B. F. (1961). Superstition in the pigeon. Journal of Experimental Psychology: General, 38, 168-172. doi:10.1037/11324-029 (Original work published 1948)

Skinner, B. F. (1969). Contingencies of reinforcement: a theoretical analysis. New York: Appleton-CenturyCrofts.

Staddon, J. E. R., \& Simmelhag, V. L. (1971). The "superstition" experiment: A reexamination of its implications for the principles of adaptive behavior. Psychological Review, 78, 3-43. doi:10.1037/h0030305

Starr, B. C., \& Staddon, J. E. R. (1982). Sensory superstition on multiple interval schedules. Journal of the Experimental Analysis of Behavior, 37, 267-280. doi:10.1901/jeab.1982.37-267

Timberlake, W., \& Lucas, G. A. (1985). The basis of superstitious behavior: Chance contingency, stimulus substitution, or appetitive behavior? Journal of the Experimental Analysis of Behavior, 44, 279-299. doi:10.1901/jeab.1985.44-279

Vadillo, M. A., Matute, H., \& Blanco, F. (2013). Fighting the illusion of control: How to make use of cue competition and alternative explanations. Universitas Psychologica, 12, 261-269. Retrieved from http://www.scielo.org.co/scielo.php?script=sci_arttext\&pid $=$ S1657-92672013000100023 
Vyse, S. A. (1997). Believing in magic: The psychology of superstition. New York: Oxford University Press.

Wagner, G. A., \& Morris, E. K. (1987). "Superstitious" behavior in children. Psychological Record, 37, 471-488. Retrieved from http://search.proquest. com/openview/eaf43a15760eab273c78fe3817f6 4a87/1?pq-origsite $=$ gscholar\&cbl $=1817765$

Weisberg, P., \& Kennedy, D. B. (1969). Maintenance of children's behavior by accidental schedules of reinforcement. Journal of Experimental Child Psychology, 8, 222-233. doi:10.1016/0022Recebido: 25/09/2016 0965(69)90097-6 